\title{
ANALISIS KEBUTUHAN PANGAN DI KECAMATAN RUMBAI PESISIR KOTA PEKANBARU
}

\author{
${ }^{1)}$ Niken Nurwati, Enny Mutryarny, Mufti \\ ${ }^{1)}$ Saff Pengajar Fakultas Pertanian Universitas Lancang Kuning Pekanbaru \\ Email : nikennurwaty@yahoo.com
}

\begin{abstract}
ABSTRAK
Pangan merupakan salah satu kebutuhan manusia yang mendasar. Penganekaragaman pangan merupakan suatu langkah strategis untuk mewujudkan ketahanan pangan dalam rangka meningkatkan kualitas sumberdaya manusia.

Permintaan pangan meningkat seiring dengan pertumbuhan penduduk. Peningkatan jumlah penduduk serta penurunan luas lahan pertanian produktif akibat konversi lahan untuk kepentingan sektor non-pertanian, menyebabkan pangan tidak cukup. Oleh karena itu perlu dilakukan perhitungan kebutuhan pangan.

Penelitian dengan judul : Analisis Kebutuhan Pangan Di Kecamatan Rumbai Pesisir Kota Pekanbaru, memiliki tujuan : a) Menganalisis kebutuhan pangan Kecamatan Rumbai Pesisir Kota Pekanbaru.b). Menganalisis potensi pengembangan tanaman pangan Kecamatan Rumbai Pesisir Kota Pekanbaru.

Hasil penelitian menunjukkan bahwa pangan yang dibutuhkan untuk memenuhi kecukupan gizi dengan standart PPH belum dapat dipenuhi dari produksi pangan dari wilayah setempat. Oleh karena itu dengan memanfaatkan sumberdaya yang ada diharapkan dapat ditingkatkan produksi pangan, antara lain ubi kayu, jagung, padi, kacang tanah, kacang hijau. Diperlukan dukungan dari berbagai pihak untuk mewujudkan hal tersebut, baik dari pemerintah, akademisi serta peranserta masyarakat.
\end{abstract}

Kata Kunci : Kebutuhan Pangan, Pengembangan Pangan

\section{PENDAHULUAN}

Pangan merupakan salah satu kebutuhan manusia yang mendasar. Penganekaragaman pangan merupakan suatu langkah strategis untuk mewujudkan ketahanan pangan dalam rangka meningkatkan kualitas sumberdaya manusia. Permintaan pangan yang meningkat seiring dengan pertumbuhan penduduk. Peningkatan jumlah penduduk serta penurunan luas lahan pertanian produktif akibat konversi lahan untuk kepentingan sektor non-pertanian, menyebabkan pangan tidak cukup. Oleh karena itu perlu dilakukan perhitungan kebutuhan pangan. Kecamatan Rumbai Pesisir merupakan salah satu kecamatan di Kota Pekanbaru, yang mengalami perkembangan penduduk. Wilayah ini merupakan wilayah pertanian kota, yang beragam mata pencaharian penduduknya. 


\section{METODE PENELITIAN}

Penelitian dilaksanakan di Kecamatan Rumbai Pesisir Kota Pekanbaru. dengan metode survey, dan pengamatan lapangan.Data yang dikumpulkan dalam penelitian ini meliputi data primer dan data sekunder. Data primer diperoleh dari wawancara dan pengamatan langsung di lapangan. Adapun data primer yang diambil meliputi : kelompok bahan pangan yang dikonsumsi rumah tangga sampel, dan pengembangan tanaman pangan di Kecamatan Rumbai. Data sekunder diperoleh dari instansi terkait, dan literatur yang ada hubungannya dengan penelitian ini.

Analisis kebutuhan pangan dilakukan berdasarkan angka PPH ketersediaan yaitu 2200 kalori/kapita/hari (Widya Karya Pangan dan Gizi, 2012). Rumus perhitungan nilai gizi (Auliana, 2001) adalah sbb:

$\mathrm{KGij}=(\mathrm{BJ} / 100) X \mathrm{Gij} X(\mathrm{BDDj} / 100)$

Kgij = Kandungan zat gizi i pada baham pangan $\mathrm{j}$ dengan berat $\mathrm{B}$ gram

$\mathrm{Bj}=$ Berat bahan pangan yang dihitung (gram)

Gij = Kandungan gizi i dalam 100 gram BDD

BDDj =Persentase bahan makanan j yang dapat dimakan (\% BDD)

Analisis potensi pengembangan tanaman pangan dilakukan dengan wawancara kepada beberapa pihak yang relevan dengan judul penelitian.

\section{HASIL DAN PEMBAHASAN}

\section{Keadaan Umum daerah}

Kecamatan Rumbai Pesisir merupakan salah satu Kecamatan di Kota Pekanbaru, dengan ketinggian 25 meter dari permukaan laut, bertopografi dataran rendah dan sedikit berbukit-bukit. Luas wilayah Kecamatan Rumbai Pesisir adalah 17,1 Km. Pada umumnya Kecamatan Rumbai beriklim tropis dengan suhu maksimum antara $23,3^{\circ}-34^{\circ} \mathrm{C}$ dengan suhu minimum berkisar antara $23,3^{\circ}-24^{\circ} \mathrm{C}$ (Kantor Camat Rumbai Pesisir).

Penduduk Kecamatan Rumbai Pesisir 67.703 jiwa, yang terdiri dari 34.664 pria dan 33.039 wanita. (Rumbai Pesisir dalam Angka,2013) 


\section{Keadaan Pertanian}

Berdasarkan ekosistem sebagian besar wilayah Kecamatan Rumbai Pesisir adalah lahan kering, terutama lahan perkebunan. Sedangkan lahan basah hanya sebagian kecil, yaitu lahan tadah hujan.

Tabel 2. Penggunaan Lahan berdasarkan Ekosistem di Kecamatan Rumbai Pesisir

\begin{tabular}{|c|l|r|r|}
\hline NO & \multicolumn{1}{|c|}{ URAIAN } & LUAS (Ha) & \multicolumn{1}{|c|}{$(\%)$} \\
\hline I & Lahan Basah & & 0,20 \\
\hline 1 & Tadah Hujan & 35,00 & \\
\hline II & Lahan Kering & & 1,84 \\
\hline 1 & Lahan Pekarangan untuk bangunan & 312,67 & 1,26 \\
\hline 2 & Tegalan & 213,50 & 78,88 \\
\hline 3 & Lahan Perkebunan & $13.409,00$ & 0,44 \\
\hline 4 & Kehutanan & 75,50 & 0,02 \\
\hline 5 & Padang rumput Penggemabalaan & 3,00 & 17,00 \\
\hline 6 & Lahan yang tidak diusahakan/lainnya & $2.934,50$ & \\
\hline III & Perairan & & 0,02 \\
\hline 1 & Setu/danau & 4,0 & 7.55 \\
\hline 2 & Kolam & $1.283,00$ & \\
\hline
\end{tabular}

Sumber : Data UPTB PP 2014

Masih ada lahan yang belum/tidak diusahakan termasuk untuk penggunaan lainnya seluas $2.934 \mathrm{Ha}$ atau sekitar 17\%. Lahan ini dimungkinan dapat untuk pengembangan budidaya tanaman pangan. Produksi pertanian di wilayah Kecamatan Rumbai Pesisir disajikan pada tabel 3.

Tabel 3. Luas Panen, Dan Produksi Pangan di Kecamatan Rumbai Pesisir Kota Pekanbaru Tahun 2013

\begin{tabular}{|c|l|r|r|r|}
\hline NO & \multicolumn{1}{|c|}{ KEL PANGAN } & L.TANAM (Ha) & L.PANEN (Ha) & PRODUKSI (Ton) \\
\hline 1 & Padi-padian & 56,9 & 27,15 & 128,72 \\
\hline 2 & Umbi-umbian & 71,08 & 22,25 & 187,15 \\
\hline 3 & Pangan hewani *- Ikan & 4,47 & & 962,2 \\
\hline 4 & Minyak \& lemak & - & - & \\
\hline 5 & Buah/biji berminyak & - & - & - \\
\hline 6 & Kacang-kacangan & 4,24 & 3,74 & 5,28 \\
\hline 7 & Gula & - & - & - \\
\hline 8 & Sayur \& buah & 311,49 & 144,92 & $3.434,84$ \\
\hline 9 & Lain-lain & 36,3 & 18,4 & 72,07 \\
\hline
\end{tabular}

Sumber : Data UPTB PP 2014

Keterangan * : tanpa ternak

Produksi pangan di Kecamatan Rumbai Pesisir, masih rendah jika dibandingkan dengan kebutuhan pangan penduduknya. Produksi ternak di Kecamatan rumbai Rumbai Pesisir disajikan pada tabel 4. 
Tabel 4. Jumlah Populasi Terbak di Kecamatan Rumbai Pesisir Kota Pekanbaru Tahun 2013

\begin{tabular}{|c|l|r|}
\hline NO & \multicolumn{1}{|c|}{ Ternak } & Jumlah (Ekor) \\
\hline 1 & Sapi & 248 \\
\hline 2 & Kerbau & 0 \\
\hline 3 & Kambing & 339 \\
\hline 4 & Babi & 780 \\
\hline 5 & Itik & 6.665 \\
\hline 6 & Ayam Buras & 9.319 \\
\hline 7 & Ayam Ras Petelur & 0 \\
\hline 8 & Ayam Ras Pedaging & 48.000 \\
\hline
\end{tabular}

Sumber : Data UPTB PP 2014

Di Kecamatan Rumbai Pesisir terdapat 6 Gapoktan 41 Kelompok Tani yang yang seluruhnya berada pada kelas pemula, dengan jumlah anggota 755 petani, 592 laki-laki dan 163 wanita tani.

\section{HASIL PEMBAHASAN}

\section{Jenis Pangan yang Dikonsumsi}

Jenis pangan yang sering dikonsumsi oleh masyarakat di Kecamatan Rumbai Pesisir disajikan pada table 5.

Tabel 5. Kelompok Pangan Yang dikonsumsi Sampel

\begin{tabular}{|c|l|l|}
\hline No & Kelompok Pangan & \multicolumn{1}{|c|}{ Jenis Komoditas yang sering dikonsumsi } \\
\hline 1 & Padi-padian & Beras \\
\hline 2 & Umbi-umbian & Ubi kayu, ubi jalar, kentang. \\
\hline 3 & Pangan hewani & Daging, ayam, ikan, telur, susu \\
\hline 4 & Minyak \& lemak & minyak sawit, margarin, \\
\hline 5 & Buah/biji berminyak & Kelapa (santan), kemiri \\
\hline 6 & Kacang-kacangan & $\begin{array}{l}\text { Kacang tanah, kacang kedelai, tahu, tempe, tauco, } \\
\text { kecap }\end{array}$ \\
\hline 7 & Gula & Gula pasir, gula merah, sirup, \\
\hline 8 & Sayur \& buah & $\begin{array}{l}\text { Bayam, kangkung, kol, kacang panjang, daun } \\
\text { singkong, pepaya, pisang,jeruk. }\end{array}$ \\
\hline 9 & Lain-lain & $\begin{array}{l}\text { Aneka bumbu \& bahan minuman spt terasi, cengkeh, } \\
\text { ketumbar, merica, pala, asam, bumbu masak, teh, } \\
\text { kopi }\end{array}$ \\
\hline
\end{tabular}

Sumber : Data primer

\section{Kebutuhan Pangan}

Hasil analisis kebutuhan pangan di Kecamatan Rumbai Pesisir tahun 2014, dengan jumlah penduduk 67.703 jiwa, disajikan pada tabel 9. Hasil 
perhitungan pada tabel 6, adalah kebutuhan pangan sesuai dengan kelompok pangan yang didasarkan pada angka PPH ketersediaan kalori 2200 kalori/kapita/hari. Jika kebutuhan ketersedian pangan sebagaimana tabel 6 tersebut dihitung kandungan proteinnya, ternyata memenuhi kebutuhan protein rata-rata 57 gram/kap/hari. Seperti disajikan pada tabel 7.

\section{Potensi Pengembangan Tanaman Pangan}

Komodi tanaman pangan yang dikembangkan di Kecamatan Rumbai adalah sbb:

Tabel 8. Sasaran Luas Tanam, Panen, Produktuvitas dan Produksi UPTB PP Rumbai

\begin{tabular}{|l|l|r|r|r|r|}
\hline NO & KOMODITI & $\begin{array}{c}\text { LUAS } \\
\text { TANAM }\end{array}$ & $\begin{array}{c}\text { LUAS } \\
\text { PANEN }\end{array}$ & $\begin{array}{c}\text { PRODUKTIVITAS } \\
(\mathrm{Kw} / \mathrm{Ha})\end{array}$ & $\begin{array}{c}\text { PRODUKSI } \\
(\mathrm{Kw})\end{array}$ \\
\hline 1 & Padi & 31 & 29 & 3,074 & 89,152 \\
\hline 2 & Kedelai & 26 & 23,4 & 4,8 & 28,08 \\
\hline 3 & Ubi Jalar & 9 & 8,1 & 9,6 & 77,76 \\
\hline 4 & Ubi Kayu & 53 & 47,7 & 16 & 763,2 \\
\hline 5 & Kacang hijau & 8 & 7,2 & 0,96 & 6,9 \\
\hline 6 & Kacang Tanah & 10 & 9 & 2 & 18 \\
\hline 7 & Jagung & 54 & 48,6 & 2,28 & 110,8 \\
\hline 8 & komposit & & & & 6,56 \\
\hline
\end{tabular}

Sumber : Data UPTB PP 2014

Jika kita bandingkan angka sasaran pengembangan tanamanan pangan di Kecamatan Rumbai Pesisir, maka dapat disimpulkan pencapaian produksi pangan ini masih sangat jauh dari kebutuhan pangan ideal. Hal ini berarti sebagian besar pangan masih harus didatangkan dari luar wilayah kecamatan. Pengembangan tanaman pangan dapat ditingkatkan lagi dengan memanfaatkan lahan yang selama ini belum dimanfaatkan yaitu sebanyak hampir 2.934,50 Ha. Lahan ini memang belum dimanfaatkan oleh masyarakat, berupa lahan kering. 
Tabel 6. Kebutuhan Pangan Kecamatan Rumbai Pesisir Tahun 2014

\begin{tabular}{|c|c|c|c|c|c|c|c|c|c|}
\hline $\begin{array}{l}\mathrm{N} \\
\mathrm{O}\end{array}$ & Kelompok Pangan & $\begin{array}{c}\text { Energi } \\
\text { (kkal/ } \\
\text { kap/hr) }\end{array}$ & $\begin{array}{c}\% \\
\mathrm{AKG}\end{array}$ & $\begin{array}{c}\text { Jumlah } \\
\text { Penduduk }\end{array}$ & $\begin{array}{c}\text { Kebutuhan } \\
\text { Kalori/kapita/hari }\end{array}$ & $\begin{array}{c}\text { Kebutuhan } \\
\text { Kalori/kapita/Th }\end{array}$ & $\begin{array}{c}\text { Rata-rata } \\
\text { Nilai } \\
\text { kalori }\end{array}$ & $\begin{array}{c}\text { Rata- } \\
\text { rata } \\
\text { BDD }\end{array}$ & $\begin{array}{c}\text { Berat } \\
\text { Kelompok } \\
\text { Pangan } \\
\text { (ton/th) }\end{array}$ \\
\hline 2 & Umbi-umbian & 132 & 6 & 67.703 & 8.936 .796 & 3.261 .930 .540 & 176 & 82 & 2.260 \\
\hline 3 & Pangan hewani & 264 & 12 & 67.703 & 17.873 .592 & 6.523 .861 .080 & 114,375 & 84,75 & 6.730 \\
\hline 4 & Minyak \& lemak & 220 & 10 & 67.703 & 14.894 .660 & 5.436 .550 .900 & 884 & 100 & 615 \\
\hline 5 & Buah/biji berminyak & 66 & 3 & 67.703 & 4.468 .398 & 1.630 .965 .270 & 180 & 100 & 906 \\
\hline 6 & Kacang-kacangan & 110 & 5 & 67.703 & 7.447 .330 & 2.718 .275 .450 & 1007 & 100 & 270 \\
\hline 7 & Gula & 110 & 5 & 67.703 & 7.447 .330 & 2.718 .275 .450 & 364 & 100 & 747 \\
\hline 8 & Sayur \& buah & 132 & 6 & 67.703 & 8.936 .796 & 3.261 .930 .540 & 50,2 & 77 & 8.439 \\
\hline 9 & Lain-lain & 66 & 3 & 67.703 & 4.468 .398 & 1.630 .965 .270 & 46,25 & 89,5 & 3.940 \\
\hline & Jumlah & 2.200 & 100 & 67.703 & 148.946 .600 & 54.365 .509 .000 & & & \\
\hline
\end{tabular}

Sumber : Analisis data sekunder

Tabel 7. Nilai Protein dalam Kebutuhan Pangan Kecamatan Rumbai Pesisir Tahun 2014

\begin{tabular}{|c|c|c|c|c|c|c|}
\hline No & Kelompok Pangan & $\begin{array}{l}\text { Berat Kelompok Pangan } \\
\text { (g/Th) }\end{array}$ & Rata-rata BDD & $\begin{array}{c}\text { Rata-rata nilai } \\
\text { protein }(\mathrm{DKBM})\end{array}$ & $\begin{array}{c}\text { Nilai Protein Dari } \\
\text { Bahan Pangan (gram) }\end{array}$ & $\begin{array}{c}\text { Nilai Protein } \\
\text { /kap/hari (gram) }\end{array}$ \\
\hline 1 & Padi-padian & 7.788 .754 .871 & 100 & 7,10 & $553.001 .595,85$ & 22,38 \\
\hline 2 & Umbi-umbian & 2.260 .206 .860 & 82 & 1,67 & $30.889 .493,75$ & 1,25 \\
\hline 3 & Pangan hewani & 6.730 .291 .747 & 84,75 & 19,7 & $1.123 .672 .684,38$ & 45,47 \\
\hline 4 & Minyak \& lemak & 614.994 .446 & 100 & 0,75 & $4.612 .458,34$ & 0,19 \\
\hline 5 & Buah/biji berminyak & 906.091 .817 & 100 & 11,50 & $104.200 .558,92$ & 4,22 \\
\hline 6 & Kacang-kacangan & 269.937 .979 & 100 & 18,38 & $49.601 .103,67$ & 2,01 \\
\hline 7 & Gula & 746.778 .970 & 100 & 0 & - & - \\
\hline 8 & Sayur \& buah & 8.438 .791 .690 & 77 & 2,31 & $150.100 .787,80$ & 6,07 \\
\hline \multirow[t]{2}{*}{9} & Lain-lain & 3.940 .124 .463 & 89,5 & 2 & $70.528 .227,89$ & 2,85 \\
\hline & Jumlah & & & & & 84,44 \\
\hline
\end{tabular}

\footnotetext{
31 Analisis Kebutuhan Pangan Di Kecamatan Rumbai Pesisir Kota Pekanbaru
} 


\section{Potensi Pengembangan Tanaman Pangan}

Komodi tanaman pangan yang dikembangkan di Kecamatan Rumbai adalah sbb:

Tabel 8. Sasaran Luas Tanam, Panen, Produktuvitas dan Produksi UPTB PP Rumbai

\begin{tabular}{|l|l|r|r|r|r|}
\hline NO & \multicolumn{1}{|c|}{ KOMODITI } & \multicolumn{1}{c|}{$\begin{array}{c}\text { LUAS } \\
\text { TANAM }\end{array}$} & $\begin{array}{c}\text { LUAS } \\
\text { PANEN }\end{array}$ & $\begin{array}{c}\text { PRODUKTIVITAS } \\
(\mathrm{Kw} / \mathrm{Ha})\end{array}$ & $\begin{array}{c}\text { PRODUKSI } \\
(\mathrm{Kw})\end{array}$ \\
\hline 1 & Padi & 31 & 29 & 3,074 & 89,152 \\
\hline 2 & Kedelai & 26 & 23,4 & 4,8 & 28,08 \\
\hline 3 & Ubi Jalar & 9 & 8,1 & 9,6 & 77,76 \\
\hline 4 & Ubi Kayu & 53 & 47,7 & 16 & 763,2 \\
\hline 5 & Kacang hijau & 8 & 7,2 & 0,96 & 6,9 \\
\hline 6 & Kacang Tanah & 10 & 9 & 2 & 18 \\
\hline 7 & Jagung komposit & 54 & 48,6 & 2,28 & 110,8 \\
\hline 8 & Jagung manis & 62 & 55,8 & 6,56 & 366,05 \\
\hline
\end{tabular}

Sumber : Data UPTB PP 2014

Jika kita bandingkan angka sasaran pengembangan tanamanan pangan di Kecamatan Rumbai Pesisir, maka dapat disimpulkan pencapaian produksi pangan ini masih sangat jauh dari kebutuhan pangan ideal. Hal ini berarti sebagian besar pangan masih harus didatangkan dari luar wilayah kecamatan. Pengembangan tanaman pangan dapat ditingkatkan lagi dengan memanfaatkan lahan yang selama ini belum dimanfaatkan yaitu sebanyak hampir 2.934,50 Ha. Lahan ini memang belum dimanfaatkan oleh masyarakat, berupa lahan kering.

\section{KESIMPULAN DAN SARAN}

\section{Kesimpulan}

a. Kebutuhan pangan di Kecamatan Rumbai Pesisir Tahun 201. Kebutuhan pangan dari kelompok padi-padian 7.789 ton, Umbi-umbian 2.260 ton, Pangan hewani 6.730 ton, minyak \& lemak 615 ton, Kacang-kacanga 270 ton, Gula747 ton, Sayur dan buah 8.439 ton, lain-lain 3.940 ton

b. Peningkatan Pengembangan Tanaman pangan dimungkinkan untuk dilakukan sesuai dengan potensi sumberdaya lahan dan sumbserdaya manusia.

\section{Saran}

Perlu peningkatan kajian dan dukungan dari berbagai pihak dalam rangka pengembangan tanaman pangan di Kecamatan Rumbai Pesisir. 


\section{DAFTAR PUSTAKA}

Alan Berg, 1986. Peranan Gizi dalam Pembangunan Nasional (Terjemahan) Rajawali.Jakarta.

Auliana Rizqie, 2001. Gizi dan Pengolahan Pangan.Adicita.Yogjakarta

Badan Ketahanan pangan : Rumusan Kesepakatan Rapat Koordinasi Dewan Ketahanan Pangan Tingkat Provinsi Riau Tanggal 27 November 2012.

Badan Pusat Statistik Kota Pekanbaru, 2013. Rumbai Pesisir Dalam Angka.

Departemen Pertanian, 2009. Aplikasi Angka Kecukupan Gizi (AKG) dan pola Pangan Harapan (PPH) Dalam Perencanaan Ketersediaan Pangan.

FAO. 1996. World Food Summit, 13-17 November 1996. Rome, Italy: Food and Agriculture Organisation of the United Nations.

Gevisioner. 2009. Strategi Penyediaan Pangan Penduduk Dalam Rangka Pencapaian Visi Riau Tahun 2020. Jurnal Teroka, Volume IX No. 2 April 2009. Badan Penelitian dan Pengembangan Propinsi Riau. Riau

Hardinsyah, Hadi Riyadi, Victor Napitupulu,2012. Kecukupan Energi, Protein, Lemak Dan Karbohidrat. Departemen Gizi Masyarakat FEMA IPB 2Departemen Gizi, FK UI.

PPK-LIPI, 2004. Ketahan Pangan Rumah Tangga di Pedesaan, Konsep dan Ukuran.

Republik Indonesia. 2002. Peraturan Pemerintah Republik Indonesia Nomor 68 Tahun 2000 Tentang Ketahanan Pangan Jakarta: Sekretaris Negara RI.

Unit Pelaksana Teknis Badan Penyuluhan Pertanian (UPTB PP), 2014. Programa Penyuluhan Pertanian UPTB PP Rumbai 